\title{
Response of 2 semiarid grasslands to cool-season pre- scribed fire
}

\author{
CARLETON S. WHITE AND SAMUEL R. LOFTIN
}

Authors are senior research scientist, Department of Biology, University of New Mexico, Albuquerque, N.M. 87131-1091; and plant ecologist, Rocky Mountain Research Station, 2205 Columbia SE, Albuquerque, N.M. 87106 (current address: Los Alamos National Laboratory, ESH-20, MS-M887, Los Alamos, N.M. 87545).

\begin{abstract}
Woody perennials have invaded semiarid grasslands throughout the Southwestern United States. This invasion was coupled with decreased grass cover and increased runoff and soil erosion. Fire, which was a natural force that shaped and maintained the grasslands, is a management tool that may aid in restoring and maintaining grass cover. However, fire also poses the risk of increasing erosion and further soil degradation because protection afforded by vegetation is reduced immediately after the fire. Using a randomized block study design, this study measured vegetation cover, soil potentially mineralizable $\mathrm{N}$, and erosion associated with the first application of prescribed fire on 2 semiarid grasslands. The potential for adverse effects from these fires was great because the fires occurred at the beginning of a drought period. However, the effects of the burn were minor relative to the effects of the drought, which caused the greatest change. Grass cover on the burn plots was nearly equal to grass cover on the controls 1 year after the fire. After 2 growing seasons, grass cover was equal on the control and burn plots. Potentially mineralizable soil $\mathbf{N}$ and sediment transport were similar on the control and burned plots during the 2 years following the fire. Thus, prescribed fire for reducing the cover of woody perennials may not increase the risk of site degradation over that caused by drought and weather fluctuations.
\end{abstract}

Key Words: Shrub control, vegetation cover, soil mineralizable $\mathrm{N}$, erosion, soil erosion bridge, drought

In the Southwestern United States, widespread fires at 5 to 10 year intervals probably maintained the semiarid grasslands (Collins and Wallace 1990, Cook 1995, Gottfried et al. 1995, Mitchell 1978, Wright 1980, Wright and Bailey 1982). Past research has demonstrated that woody perennials invaded grasslands in the absence of fire (Briggs and Gibson 1992, Wright

The authors are grateful for all the people who helped in this research; Richard Gatewood, Ruben Leal, Randi Paris, John Craig, Chris Thomas, Steve Hofstad, Robyn Phillips, Ray Romero, Wendy Jones Brunnemann (City of ABQ Open Space), all the people who actually performed the prescribed burn (Cibola National Forest-Sandia Ranger District, State Forestry, Placitas Fire Brigade, Sandoval County Fire Department, New Mexico Forestry and Resources Conservation), and the reviewers whose suggestions improved the manuscript. This work was supported by the Rocky Mountain Research Station of the USDA Forest Service, by grants from the National Science Foundation (No. BSR-88-11906 and DEB9411976), and by a grant from the Cibola National Forest. This is Sevilleta LongTerm Ecological Research Program Pub. \#144.

Manuscript accepted 28 Mar. 1999.

\section{Resumen}

Las especies arbustivas leñosas perennes han invadido los pastizales semiáridos del sudoeste de los Estados Unidos. Esta invasión se acompaño de una reducción de la cobertura de zacates y un aumento de escurrimiento y erosión del suelo. El fuego, el cual es una fuerza natural que moldea y mantiene los pastizales, es una herramienta de manejo que puede ayudar a restaurar y mantener la cobertura de zacates. Sin embargo, el fuego también posee el riesgo de incrementar la erosión y la posterior degradación del suelo, esto debido a que la protección brindada por la vegetación se reduce inmediatamente después del fuego. En este estudio se midió la cobertura de vegetación, el nitrógeno potencialmente mineralizable del suelo y la erosión asociada con la primer aplicación de fuego prescrito en dos pastizales semiáridos, los datos se analizaron con un diseño de bloques al azar. El potencial de efectos adversos de estos fuegos fue alto porque ocurrieron al inicio de un período de sequía. Sin embargo, los efectos del fuego fueron menores comparados con los de la sequía, la cual causó el mayor cambio. Un año después del fuego, la cobertura de zacate en las parcelas quemadas fue casi igual que la cobertura de zacates en las parcelas control. Después de 2 estaciones de crecimiento, la cobertura de gramíneas fue igual en las parcelas quemadas y las parcelas control. Durante los 2 años siguientes a la quema, el nitrógeno potencialmente mineralizable del suelo y el transporte de sedimento fueron similares tanto en las parcelas quemadas como las control. Así, el riesgo de degradación del sitio por el fuego prescrito para reducir la cobertura de especies leñosas perennes no es mayor que la degradación causada por la sequía y las fluctuaciones climáticas.

1980). Invasion by shrubs and trees occurred after periods of intensive grazing coupled with periods of drought that began in the late 1800s and extended to the middle 1900's (Buffington and Herbel 1965, Frederickson et al. 1998). In the absence of grazing impacts, fire suppression in the mid-1900's created optimum conditions for shrub invasion (Brown 1982). Soil-binding perennial grasses have been replaced with shrubs such as mesquite Prosopis sp.), burroweed (Isocoma tenuisecta Greene), snakeweed (Gutierrezia sarothrae (Pursh) Britt. \& Rusby), and fourwing saltbush (Atriplex canescens (Pursh) Nutt.) in lower elevation and drier sites (Brown 1982), with juniper (Juniperus sp.) and Piñon (Pinus edulis Engelm.) invading at higher elevations or wetter sites (Davenport et al. 1998). Burroweed and snakeweed, in particular, have invaded or replaced grasslands on millions of 
acres in the Southwest (Brown 1982).

In New Mexico, sediment from rangelands constitutes the second leading cause of stream impairment by nonpoint source pollutants (NMWQCC 1994). Sediment represents a direct degradation to water resources, but it also represents the loss of soil nutrients and potential productivity from the rangelands. Erosion in the Southwest is episodic in nature, with most soil movement occurring after large, intense storms (DeBano 1977, DeBano et al. 1998, Wilcox 1994). Erosion is initiated by raindrop impaction, which breaks down soil aggregates and suspends clays in surface waters (Brooks et al. 1991). A decrease in vegetation, which intercepts raindrops and protects soil aggregates from raindrop impact, increases bare soil that is very susceptible to movement in rainsplash. The infrequent "big" storms are the major cause of erosion and carry a disproportionately large amount of sediment (DeBano 1977). Arroyo cutting during these runoff events favors shrubs that can reach deeper soil moisture with their root system and out-compete grasses with more shallow root systems, which may cause a further decline in grass cover (Wood et al. 1987). These "flash flood" events contribute large amounts of sediment to flood control structures, irrigation ditches, perennial streams and stream diversion structures. An average of 80,000 cubic yards of sediment is removed from the flood control system in the Albuquerque metropolitan area each year (Albuquerque Metropolitan Area Flood Control Authority, personal communication).

Invasion of grasslands by desert shrubs has increased bare soil, erosion, and runoff in central New Mexico (Weltz and Wood 1986) and in southern Arizona (Parsons et al. 1996). However, Belsky (1996) cited a number of studies where expansion of pinyon-juniper woodlands into grasslands did not lead to greater erosion. Davenport et al. (1998) provided a conceptual model that involved soil erosion thresholds to explain why some systems show large increases in erosion with woodland invasion and others do not. As vegetation cover declines with shrub invasion, Davenport et al. (1998) demonstrated how a system could cross a threshold in ground cover, resulting in a large increase in the connectivity of soil patches that contribute to runoff and a large increase in erosion. Conversely, erosion may decline dramatically if grass cover can be increased and shrubs and bare soils decreased (Brooks et al. 1991, Morgan and Rickson 1995).

Runoff and erosion also increases fol- lowing a drought or when precipitation occurs during a drought. Molles et al. (1992) reported that periods of high runoff follow periods of winter/spring drought in the semiarid Southwest. They provided examples of streams that demonstrate a hyperbolic relationship between runoff and precipitation where the generally positive relationship between runoff and precipitation changes below a certain amount of precipitation and runoff increases with lower precipitation. Mechanisms proposed by Molles et al. (1992) to explain this phenomenon include: (1) decreased vegetation and herbaceous cover during drought increases the area subject to rainsplash, which increases runoff and sediment transport; (2) soil hydrophobicity (water-repellency) increased during drought and increased runoff; and (3) increased bare soil and the associated solar/albedo relationships may have contributed to generation of higher-intensity summer thunderstorms following drought. Regardless of the specific causes, variation in local weather patterns (in contrast to global climate change) can cause variation in runoff and erosion, which may accelerate erosion in grasslands following shrub invasion. A major, region-wide, record-setting drought occurred during the 1950's (Betancourt et al. 1993) from which the region may still be showing effects (Frederickson et al. 1998).

Perhaps the most cost-effective management tool for shrub control is through the use of prescribed fire. Fire favors grass growth by killing shrubs (reducing competition for shallow soil moisture), increases essential nutrients through ash deposition (DeBano et al. 1998), reduces litter that acts as mulch, and increases light at the soil surface (Wright 1980). However, the use of fire faces several potential problems in shrub-invaded grasslands. The lack of fuel continuity can prohibit a fire from carrying across the landscape, except when pushed by high winds that usually exceed those allowed under current burn prescriptions. Areas with very dispersed fuels may have a higher treatment cost per unit area because they may require multiple applications of fire to significantly reduce shrub cover. Loss of shrub and grass canopy following fire increases the potential for soil erosion. The area remains more susceptible to erosion until the grass canopy can regain or exceed pre-burn coverage. The combination of increased available nutrients and reduced vegetation cover creates the possibility for significant loss of nutrient and soil resources through wind and rain erosion (Baker 1990,
Vitousek and Howarth 1991). Also, exposure of bare soil may favor broom snakeweed germination and establishment (McDaniel et al. 1997), which could increase rather than decrease shrub cover in later years.

The management objective for the prescribed fires in this study was to reduce shrub cover for maintenance of local grasslands. The objective of this research component was to document the effects of cool-season prescribed fire in 2 semi-arid grasslands on vegetation cover-type (grass, shrub, or bare ground), potentially mineralizable $\mathrm{N}$ (as a measure of site fertility), and soil erosion. Hypothesized patterns included: (1) after an initial decline in vegetation cover, grasses should respond more rapidly than shrubs and achieve greater cover relative to shrubs; (2) the amount of mineralizable $\mathrm{N}$ should increase following the fire, but mineralizable $\mathrm{N}$ should return to that of control or unburned soils following regrowth of vegetation; and (3) high intensity precipitation could increase erosion following burning until the vegetation cover recovers and potential for erosion would decline. This article presents the 2-year results of the first in what is expected to be the repeated use of prescribed fire to reduce cover of perennial woody species in semiarid grasslands in central New Mexico and to reduce soil erosion.

\section{Methods}

\section{Site Description}

The research is being conducted at 2 study sites near Albuquerque, N. M. The Bernalillo Watershed lies on the mesa north of the City within the Cibola National Forest. The West Mesa site lies on the mesa west of the City and belongs to the Open Space Division of the Parks and Recreation Department. The elevation of the Bernalillo Watershed is about 1,660 $\mathrm{m}$ and the West Mesa site is about 1,820 $\mathrm{m}$. The Bernalillo Watershed soil is a clayey loam and the West Mesa soil is a fine sandy loam (C.S. White, unpublished data, 1996). Dominant perennial grasses on the Bernalillo Watershed were: black, blue, and sideoats grama (Bouteloua eri opoda (Torr.) Torr., B. gracilis (Willd. ex Kunth) Lag. ex Griffiths, B. curtipendula (Michx.) Torr., respectively); purple 3awn (Aristida purpurea Nutt.); galleta (Hilaria jamesii (Torr.) Benth); and dropseed (Sporobolus sp.). The West Mesa grassland represents a Great Basin Desertscrub/Desert Grassland ecotone, 
a

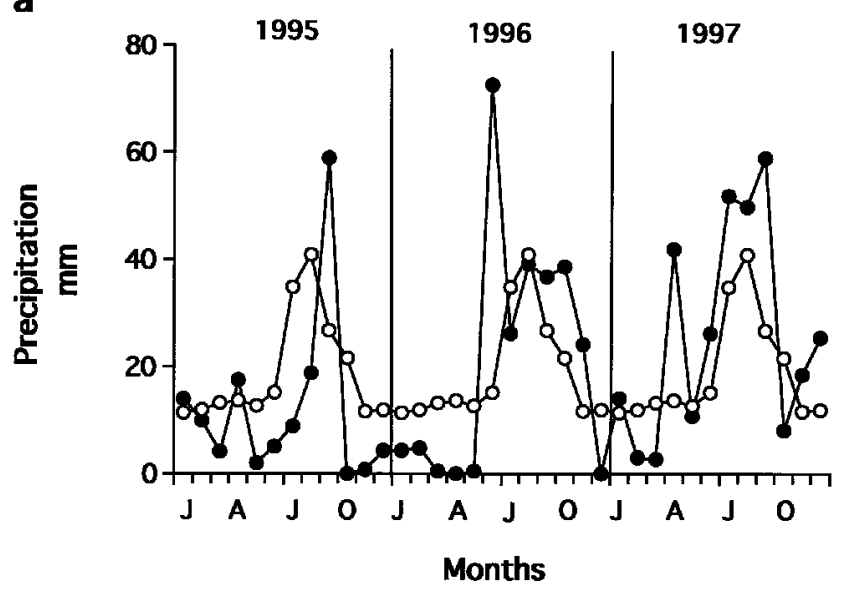

b

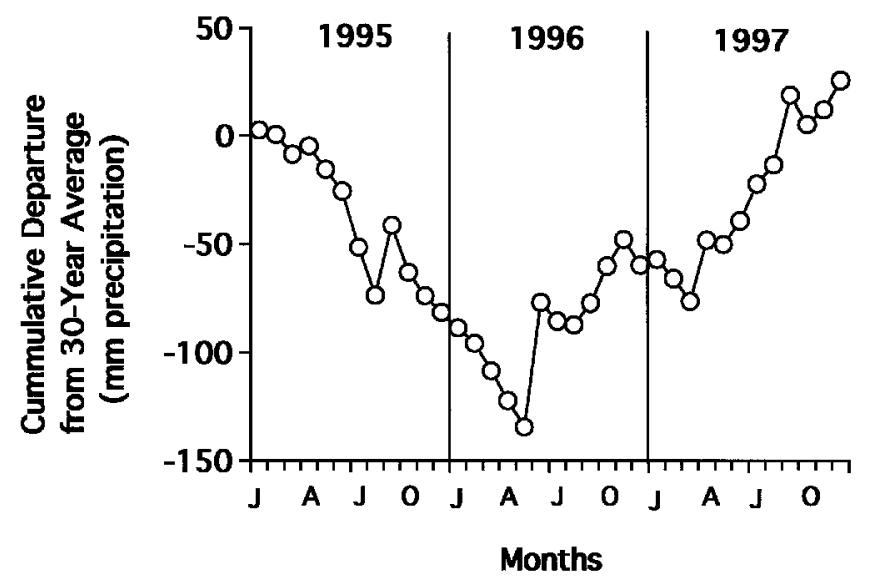

Fig. 1. Monthly mean precipitation volume for the period from 1960 through 1990 (open) and monthly precipitation (solid) during 1995, 1996, and 1997 for the Albuquerque International Airport station of the National Weather Service (a), and cumulative departure from monthly means for the period from 1960 through 1990 during the years of $\mathbf{1 9 9 5}$ through 1997 (b)

and the Bernalillo Watershed represents a Plains Mesa Grassland/Desert Grassland ecotone (Brown 1982). Dominant perennial grasses on the West Mesa were: Indian ricegrass (Oryzopsis hymenoides (Roem \& Schult.) Ricker): needle-and-thread grass (Stipa comata (Trin. \& Rupr.)); purple threeawn; galleta; black grama; and dropseed. Within the study sites, broom snakeweed was the dominant woody perennial (included as shrub) at both sites. Other shrubs included fourwing saltbush (Atriplex canescens (Pursh) Nutt.), winter fat (Krascheninnikovia (Ceratoides) lanata (Pursh) Guldenstaedt), sand sage (Artemisia filifolia Torr.), and one-seed juniper (Juniperus monosperma (Engelm.) Sarg.).

Annual precipitation for both sites averages about 200 to 250 millimeters. With the exception of 1 month, precipitation in the area around Albuquerque, N.M., during 1995 and the first 5 months of 1996 was consistently less than the monthly mean of the previous 30 years (Fig. 1a). Cumulative monthly departure from the 30 -year mean precipitation values indicate the drought period reached a maximum in May of 1996, after which slightly higher than normal precipitation generally occurred through the rest of 1996 and 1997 (Fig.1b). The normal growing period for this region is from March through September.

Livestock grazing was stopped in 1947 on the Bernalillo Watershed and in the early 1970's on the West Mesa. The Bernalillo Watershed had extensive flood and erosion control features constructed by the Soil Conservation Service and the
Forest Service in the 1950s, including steep-slope terraces, furrow plowing, pitting, check dams and grass seeding. These efforts followed blockage of the main north-south highway with sediment contributed during a flood in 1954. Surface disturbance at the West Mesa includes abandoned roads for powerline construction and use by off-road vehicles before the early 1970's. Sediment and runoff from the West Mesa are direct concerns to the local flood control authority.

\section{Experimental Design}

Each site includes 8 plots; 4 control and 4 burned, which were arranged in a randomized block design as described by Hurlbert (1984). At the Bernalillo Watershed site, 6 plots ( 3 pairs of treatment and control) are located on 1 mesa, while the other 2 ( 1 treatment and 1 control) are located on a mesa to the south. On the West Mesa, plots were arranged in a linear fashion along the contour below a ridge-line. At both sites, each plot is 1 ha (100 $\mathrm{m}$ on a side) with at least $30 \mathrm{~m}$ separating the plots. Soil and vegetation sampling took place within a $60 \mathrm{~m}$ by $60 \mathrm{~m}$ area within each 1-ha plot to protect against edge effects (Fig. 2). Within each plot, 3 permanently marked $60-\mathrm{m}$ lines were used for vegetation cover and density measurements. Soils were collected by cover-type (shrub, grass, or bare soil) along 3 adjacent $60-\mathrm{m}$ lines. In the Bernalillo Watershed, each plot had two, 3 X 10 m runoff-erosion collectors (described below) with only 1 per plot at the West Mesa because concern for archeological resources.

\section{Prescribed Fires}

The Bernalillo Watershed was treated with prescribed fire 15-16 November, 1995 , with a total of about 168 ha burned. The experimental plots were within the burned area. The control plots were protected by fire-retardant foam applied around their perimeters. Weather conditions were favorable for prescribed burning with seasonably warm temperatures (about $55^{\circ} \mathrm{F}$ ), moderate relative humidity (20 to $30 \%$ ), and light winds (0 to $10 \mathrm{mph}$ ) from the WNW in the morning, shifting to light with gusts (5-10 mph, gusts to 20) from the $\mathrm{SW}$ in the afternoon. The fuels were discontinuous, which resulted in patchy coverage by the fire. Lines of fire were set with drip torches at about $10 \mathrm{~m}$ intervals across the area. Fire was set to large individual patches that did not burn from the original drip-lines. 


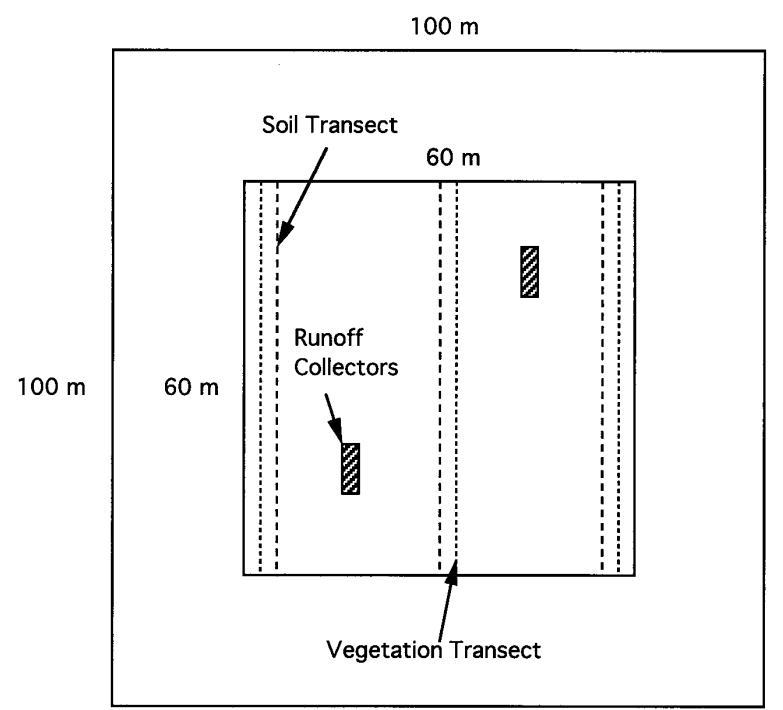

Fig. 2. Design of experimental plots showing the interior $60 \mathrm{~m}$ by $60 \mathrm{~m}$ area actually sampled, the soil and vegetation transects (dashed lines) and the relative placement of the runoff collector (rectangular shaded area in plot). Erosion bridges were installed about $30 \mathrm{~cm}$ from the border of the runoff collector centered along the top and one side of the collector. Sediment was trapped in rain gutter connected to a 20 -liter bucket at bottom of of the collector.

The West Mesa site was treated with prescribed fire 14 February, 1996. At this site, only the treatment plots were burned. Weather conditions were favorable for prescribed burning with warm temperatures for the season $\left(55-58{ }^{\circ} \mathrm{F}\right)$, moderate relative humidity $(17-25 \%)$, and light $(\leq 7$ $\mathrm{mph}$ ) but steady winds from the WSW. Fuels were more continuous at this site and the grasses were of taller stature, which allowed for nearly complete burn coverage. The plots were blacklined on the downwind sides, then lit across the windward side. The fire moved with the wind across the entire plot. Rate of spread was about 0.1 to $0.3 \mathrm{~m} \mathrm{sec}^{-1}$ with average flame length of about $0.2 \mathrm{~m}$.

\section{Vegetation Community Structure Analysis}

Aboveground cover of individual plant species, as well as non-vegetation ground cover by categories (bare soil, litter, gravel and rock), were measured using the Community Structure Analysis technique (Pase 1981). We estimated percent cover by species on a 5 by $10-\mathrm{cm}$ grid at $1-\mathrm{m}$ intervals along each of the three, $60-\mathrm{m}$ vegetation transects (a total of 180 cover samples). These transects were measured before the prescribed fire, after the prescribed fire (within 3 months at the Bernalillo Watershed and within 1 month at the West Mesa), and after the first and second growing seasons after the fire.
Cover by grass or shrub was determined by summing of the respective species' cover.

\section{Soil Measurements and Analyses}

Soil samples were collected 4 times at both sites; before the prescribed fire, shortly after the prescribed fire, and following the first and second growing seasons after the fire. Surface soil samples were collected under 3 cover-types (shrub, grass, and bare soil) by taking $4-\mathrm{cm}$ wide cores to a depth of 20 $\mathrm{cm}$ at 2 locations along three, $60-\mathrm{m}$ belt transects inside the sampling area. The 6 soil cores of each cover type from each plot were composited into a single sample. This sample design produced 1 composite sample from each plot for bare, grass, and shrub cover-types (sample-size of 4 for treatment and control).

Samples were transported on ice to the University of New Mexico, where they were sieved $(2 \mathrm{~mm})$, mixed, and stored at $5^{\circ} \mathrm{C}$ for further analyses. After determining water-holding capacity (WHC)(White and McDonnell 1988), a portion of each sample was adjusted to $50 \%$ of determined WHC and up to 11 subsamples were apportioned into plastic cups. Each cup contained approximately $30 \mathrm{~g}$ dry-weight mineral soil. One subsample of each sample was immediately extracted with 100 $\mathrm{ml} 2 \underline{\mathrm{N}} \mathrm{KCl}$ for $\mathrm{NH}_{4}{ }^{+-\mathrm{N}}$ and $\mathrm{NO}_{3}{ }^{-}$ $-\mathrm{N}+\mathrm{NO}_{2}{ }^{-}-\mathrm{N}$ analyses. The remainder of the cups were covered with plastic wrap, sealed with a rubber band, and incubated in the dark at $20^{\circ} \mathrm{C}$. The plastic wrap minimized water loss during incubation, yet exchange of $\mathrm{CO}_{2}$ and $\mathrm{O}_{2}$ was sufficient to keep the subsamples aerobic during incubation. Moisture content was monitored by mass loss and replenished as needed. At weekly intervals, 1 subsample of each sample was removed and extracted with $\mathrm{KCl}$ for $18-24$ hours. The clarified $\mathrm{KCl}$ was filtered through a Kimwipe ${ }^{\circledR}$ and analyzed for $\mathrm{NH}_{4}{ }^{+-\mathrm{N}}$ and $\mathrm{NO}_{3}{ }^{-}-\mathrm{N}+\mathrm{NO}_{2}$ $-\mathrm{N}$ on a Technicon AutoAnalyzer (Technicon, Tarrytown, N.Y.) as described in White (1986). Potentially mineralizable $\mathrm{N}$ equalled the amount of $\mathrm{N}$ (sum of $\mathrm{NH}_{4}-\mathrm{N}$ and $\mathrm{NO}_{3}-\mathrm{N}$ ) at the end of the 70-day incubation period. Water content of the composited sample was measured gravimetrically after 24-hour desiccation at $105^{\circ} \mathrm{C}$. Soil texture was measured by the hydrometer method (Day 1965). These sampling and analysis methods allowed for the determination of soil characteristics by cover-type.

\section{Sediment Yield}

Runoff-sediment collectors, designed after those used by the Water Erosion Prediction Project (WEPP; USDA, 1196 Building SOIL, Purdue University, West Lafayette, Ind. 47907-1196), measured 3 by $10 \mathrm{~m}$. Placement of the collectors at the West Mesa site were negotiated with and approved by Albuquerque Open Space archaeologists to minimize or eliminate soil disturbance and damage to articles of archeological value. Following site approval by the State Historic Preservation Office, 1 collector per plot was installed at the West Mesa site. Two collectors per site were installed at the Bernalillo Watershed. All collectors were placed on slopes representative of the area; depressions were avoided. The average maximum change in elevation across the collectors was $1.18 \mathrm{~m}$ at the Bernalillo Watershed and $1.12 \mathrm{~m}$ at the West Mesa. At both sites, change in elevation across the runoff-sediment collectors was not significantly different between the plots to be treated with fire and the controls. Flashing was placed around the perimeter of the collectors after the fire treatments because we did not want to impede the fire spread with the flashing and the associated disturbance from installation. Along the bottom 3-m side, a plastic raingutter was installed at ground level to collect runoff and sediment (Fig. 2). Galvanized flashing was attached with a hinge to each gutter and secured to allow about a $3-\mathrm{cm}$ opening for sediment and runoff to enter the gutter. At the end of the gutter, a hole was dug and a 20 -liter bucket was placed in the hole and attached to the end-cap on the gutter by a section of garden hose. Both sediment in the gutter and bucket were collected at periodic intervals the first year. Sediment and runoff occurred primarily with summer rains. After the first year (1996), it was determined that sediment trapped in the buckets was insignificant relative to that in the raingutter, and only sediment in the raingutter was collected after the first year. This experimental design resulted in 4 treatment and 4 control sediment samplers at the West Mesa site, and 8 treatment and control sediment samplers at the Bernalillo Watershed (2 collectors per plot). 


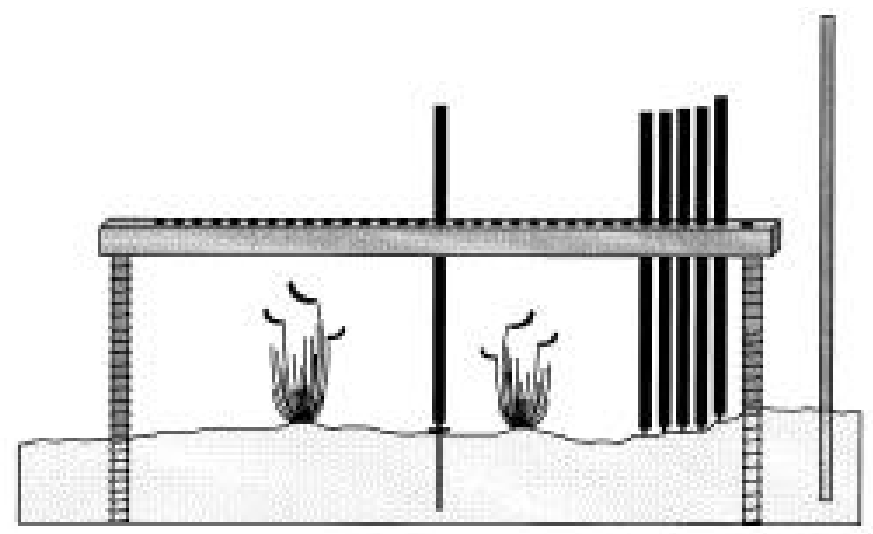

Fig. 3. Schematic drawing of soil erosion bridge showing end rebar, center nail and 5 measuring pins.

\section{Soil Erosion Bridge}

Change in soil microtopography within each runoff collector was monitored using 2 soil erosion bridges established within the area of the runoff-sediment collectors prior to the burn ( 1 bridge parallel to the top and 1 centered along the side of each collector; Fig. 2). A soil erosion bridge measures small-scale changes in soil microtopography (Shakesby 1993, Wilcox et al. 1994). The purpose of the bridge is to accurately determine small changes in soil elevation over time. Following a burn, removal of vegetation could coincide with soil loss. Regrowth of the vegetation may entrap wind-blown soil. Rain splash could transport soils from bare areas to vegetated areas. Movement of soil at this scale could result in a simple redistribution of soil with little net gain or loss. Similar to the pattern described by Watt (1947), the soil surface may rise as individual plants become established and mature, then degenerate upon plant mortality, but the area as a whole could remain in equilibrium with simple redistribution occurring within the area.

The actual bridge was constructed from an aluminum bar ( $35 \mathrm{~mm}$ square), $1.5 \mathrm{~m}$ in length, with 31 holes machined and fitted with brass bushings at $5 \mathrm{~cm}$ intervals (Fig. 3). The bridge is situated on 2 permanent rebar stakes, leveled with the help of a bubble level on the bridge, and secured with wood shims to prevent movement of the bridge during measurements. To increase the accuracy of this method, a spike with a dimple in the head is driven into the ground below the center pin (hole \#16). An aluminum pin is then inserted through the bridge and into the dimple in the head of the nail. The end rebar stakes and the center nail create a 3 point line, which increases the accuracy over what would normally be a 2 point line (Shakesby 1993, Wilcox et al. 1994).
Once the bridge is secured, pins are inserted through holes in the bridge to the soil surface and the portion of each pin extending above the bar is measured. The 30point profile reflects the soil surface topography. The soil erosion bridges were measured upon installation in the summer of 1995, immediately after each fire, and twice each year in 1996 and 1997.

\section{Statistical Analyses}

Each site (Bernalillo and West Mesa) scribed fire on soil potentially mineralizable $\mathrm{N}$ was analyzed using Analysis of Variance (ANOVA) procedures in SAS (SAS 1989). Soil bridge measurements and sediment transport were analyzed using repeated measures ANOVA procedures in SAS, which generated an analysis for the treatment, collection, and their was analyzed separately. Effect of pre-

interaction factors. Effect of the prescribed fire on vegetation cover was determined using the GLM repeated measures procedure on SPSS/PC+ 4.0 (SPSS 1990). Unless otherwise indicated, a significance level of $\mathrm{P} \leq 0.05$ was used.

\section{Results}

\section{Bernalillo Watershed: Vegetation Cover}

Vegetation cover both before and after the prescribed fire was relatively sparse and patchy, which lead to high within treatment variances (note large error bars on Fig. 4). All cover-types declined from May 1995 to Feb. 1996 ( $\mathrm{P}<0.05)$, which was during the period of below-normal precipitation (Fig. 1). The decline in grass cover was greatest on the burned plots, as expected, but grass cover on the burned plots was not significantly different than grass cover on the control plots. Total vegetation and grass cover increased between Feb. 1996 and Jan. 1997; however, shrub cover declined slightly in both the control and treatment plots. By Nov. 1997, grass cover was equal on the burned and control plots, while shrub cover declined or was unchanged. For total vegetation cover, grass cover, and shrub cover, treatment was not a significant factor, nor was the time-of-collection $\mathrm{x}$ treatment interaction. Time of collection was significant for the change in vegetation between May 1995 and Feb. $1996(\mathrm{P}=0.001)$ and between Feb. 1996 and Jan. 1997 ( $\mathrm{P}=0.038)$, but not significant between Jan. and Nov. 1997.

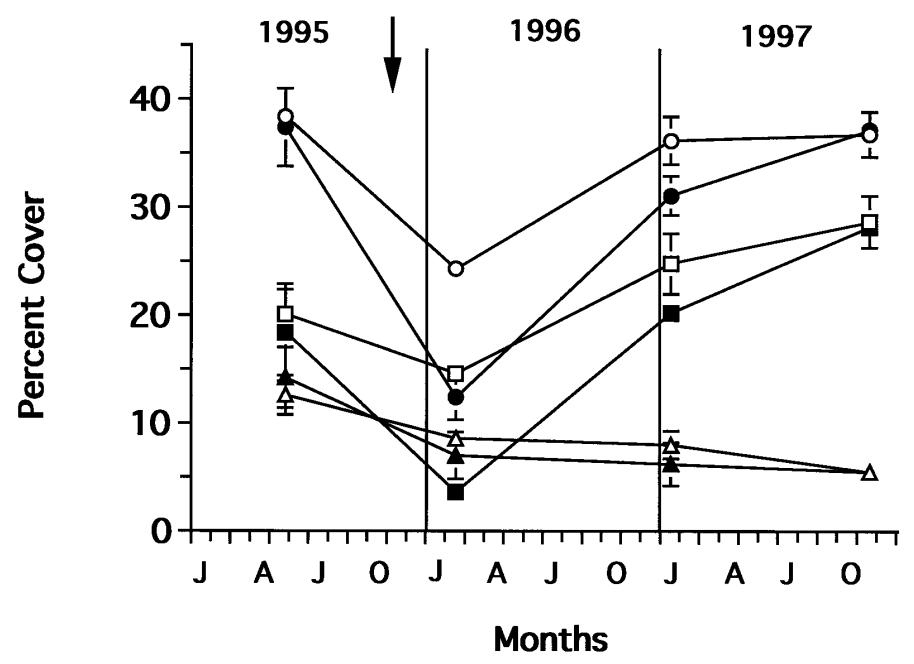

Fig. 4. Changes in mean vegetation cover (circles, total cover; squares, grass cover; triangles, shrub cover) on the control (open symbols) and burned (filled symbols) plots at the Bernalillo Watershed. Bars with each symbol, when large enough to be seen, represent 1 standard error the mean $( \pm \mathrm{SE})$. Arrow indicates when the prescribed burn occurred. 


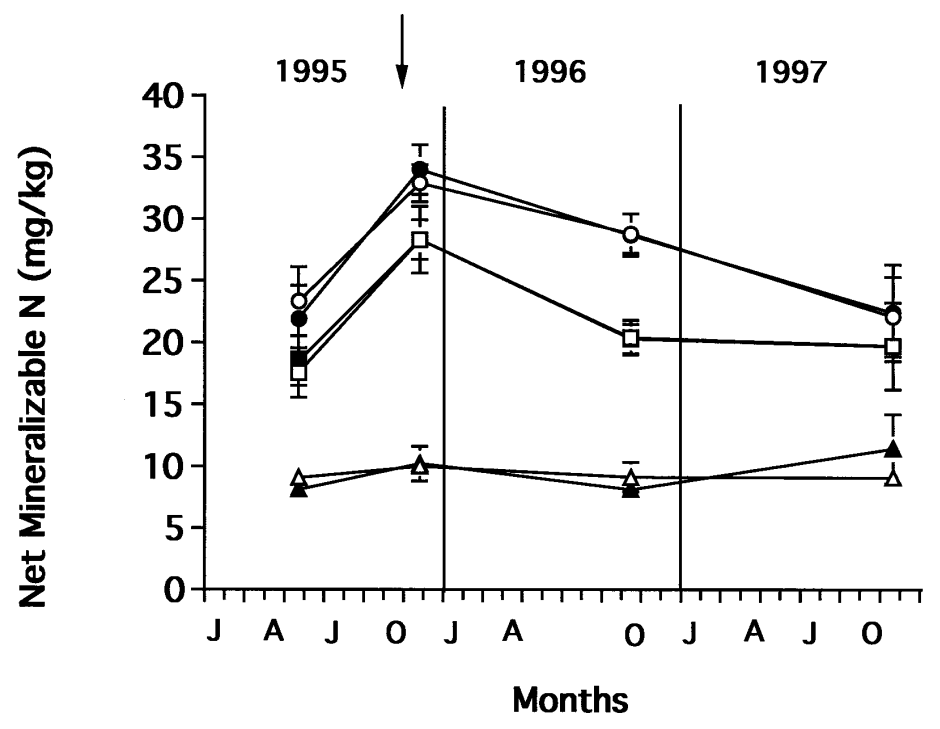

Fig. 5. Changes in mean $( \pm \mathrm{SE}) 70$ day mineralizable $N$ content of soils beneath different vegetation cover-types (circles, shrub; squares, grass; triangles, bare soil) on the control (open symbols) and burned (filled symbols) plots at the Bernalillo Watershed. Arrow indicates when the prescribed burn occurred.

\section{Mineralizable N}

Potentially mineralizable $\mathrm{N}$ was greatest in soils under shrub, slightly lower in soils under grass, and lowest in bare soils (Fig. 5) for each collection. Mineralizable $\mathrm{N}$ in both treatment and control samples increased after fire, decreased in the Oct. 1996 collection, and stayed the same or declined slightly by the Nov. 1997 collection (Fig. 5). The fire treatment and the interaction of fire and time of collection were not significant factors for mineralizable $\mathrm{N}$, but time of collection was highly significant $(\mathrm{P}=0.003)$.

\section{Erosion}

The amount of sediment obtained in each collector was highly variable in 1996 following the fire in both treatment and control plots (Fig. 6). Although the means of the treatment plots were consistently higher than the means of the controls over the first summer following the burn, the treatment was not significant $(\mathrm{P}=0.102)$ for sediment yield (in part due to the high within-treatment variance). Time of collection was a highly significant factor $(\mathrm{P}<$ 0.001 , while the treatment $\mathrm{x}$ time-of-collection interaction factor was nearly sig-

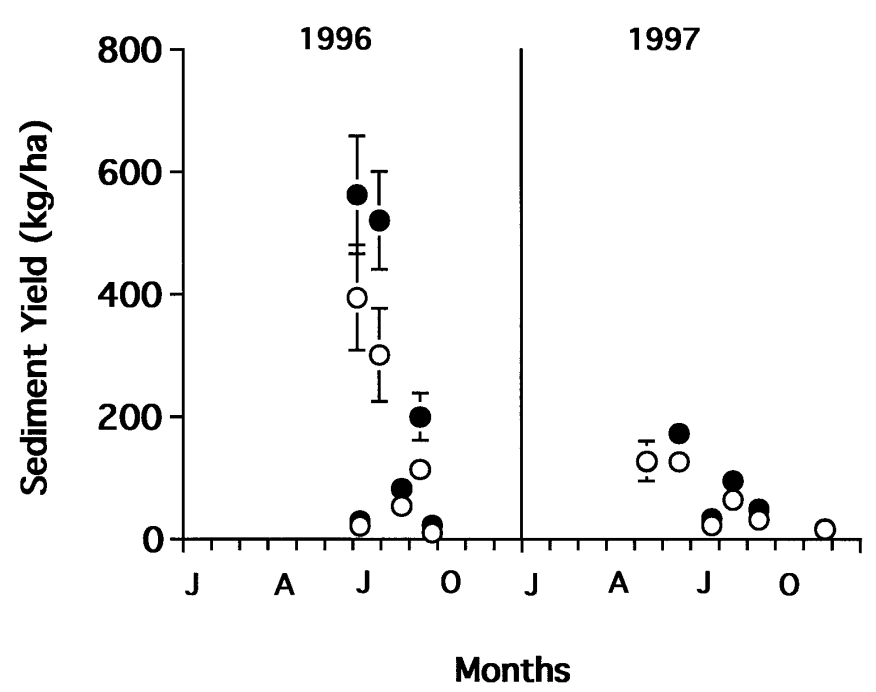

Fig. 6. Amount of mean $( \pm \mathrm{SE})$ sediment yield from the runoff collectors in the control (open circles) and burned (filled circles) plots during 1996 and 1997 at the Bernalillo Watershed. When paired filled circle is not visible, the values of control and burned plots are nearly equal. The first runoff events occurred in late June 1996.

nificant $(\mathrm{P}=0.052)$. There was a general decline in sediment yield over the course of 1996. During 1997, erosion generally declined over the course of the summer in both control and burned plots, but there was no significant difference between the treatment and control plots. Total sediment yield was much lower the second year relative to the first year on all plots ( 898 and $1,420 \mathrm{~kg} \mathrm{ha}^{-1}$ the first year in control and burn, respectively, versus 392 and $495 \mathrm{~kg} \mathrm{ha}^{-1}$ the second year from the same plots).

\section{Soil Erosion Bridges}

The repeated measures ANOVA identified that treatment, time of collection, and their interaction were all significant factors $(\mathrm{P}=0.038, \mathrm{P}=0.001$, and $\mathrm{P}=0.045$; respectively) for the change in soil microtopography in the Bernalillo Watershed. Both treatment and control soils show a general decline in soil surface (representing net erosion) through 1995 and 1996 (Fig. 7); however, both the burned and control plots show a net rise in both collections in 1997. The soil surface in the control plots is nearly equal to the preburn surface by Nov. 1997 with the burn plots slightly lower (but not significant).

\section{West Mesa \\ Vegetation Cover}

Before the prescribed fire, vegetation cover was relatively uniform across the plots and the grasses were taller than at the Bernalillo Watershed, which led to much more uniform coverage by the prescribed fire treatment. In 1995 before treatment, total cover, grass cover, and shrub cover were similar between the treatment and control plots (Fig. 8). All cover types on the control plots did not show a significant change between the 1995 collection and the Feb. 1996 collection after the fire, but all cover types were significantly lower on the burned plots. By Dec. 1996, grass cover on the burned plots increased from $0.7 \%$ cover in the post burn to $20.2 \%$ (significant at $\mathrm{P}<0.05$ ), while grass cover on the control plots increased from 21.1 to $25.8 \%$ (not significant, $\mathrm{P}>0.05$ ). By the Dec. 1996 collection, grass cover on the control and burned plots was not significantly different. Grass cover on the burned plots was nearly identical to grass cover on the control plots in the Dec. 1997 collection (29.7 and 30.4 percent grass cover, respectively). Shrub cover was significantly reduced on the burned plots after the fire and remained low through Dec. 1997. Shrub cover in the control plots did not change significantly during this study. For 


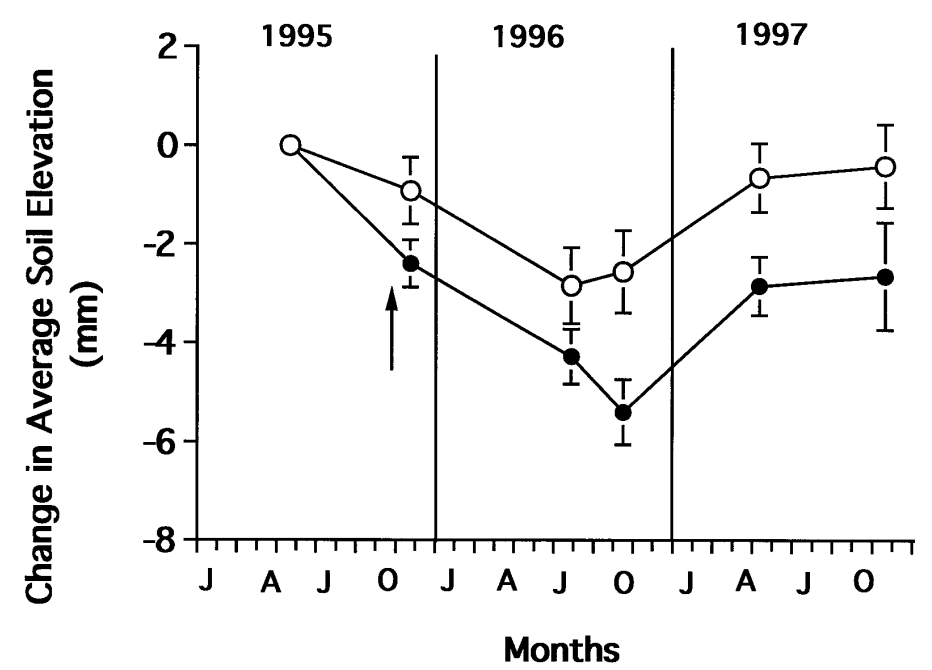

Fig. 7. Mean $( \pm \mathrm{SE})$ net change in the soil surface measured below the erosion bridges within the control (circles) and burned (filled circles) plots at the Bernalillo Watershed. Arrow indicates when the prescribed burn occurred.

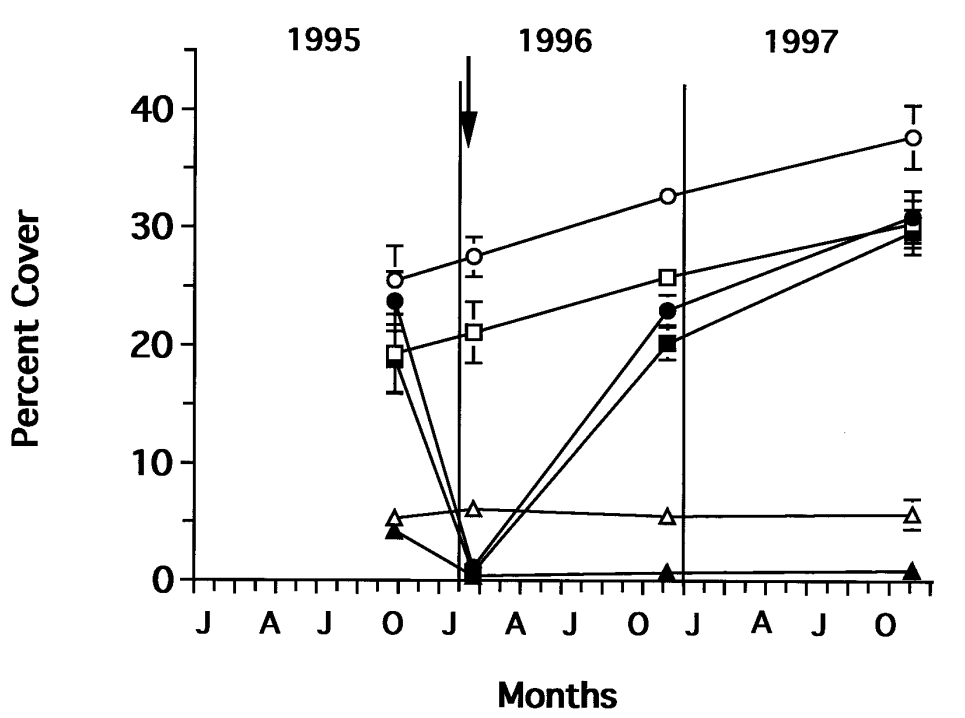

Fig. 8. Changes in mean $( \pm \mathrm{SE})$ vegetation cover (circles, total cover; squares, grass cover; triangles, shrub cover) on the control (open symbols) and burned (filled symbols) plots at the West Mesa. Arrow indicates when the prescribed burn occurred.

total vegetation cover, grass cover, and shrub cover, treatment and the time-ofcollection $\mathrm{x}$ treatment interaction factors were significant $(\mathrm{P} \leq 0.05)$.

\section{Mineralizable N}

The repeated measures ANOVA identified time of collection to be the only significant factor $(\mathrm{P}<0.001)$ for mineralizable $\mathrm{N}$ in soils of the West Mesa (Fig. 9). Mineralizable $\mathrm{N}$ increased (significant at $\mathrm{P}<0.05$ ) in all soil-types following the prescribed fire in both treatment and control plots, except in soils under grass in the control plots. All soils showed a decline in mineralizable $\mathrm{N}$ by the Dec. 1996 collection. There were only slight changes in mineralizable $\mathrm{N}$ between the Dec. 1996 and Dec. 1997 collections for all soiltypes.

\section{Erosion}

Treatment, time of collection, and their interaction were not significant factors for soil erosion at the West Mesa site. Variance was very high in all collections in both the treatment and control plots. High variance and small sample size (4 plots per treatment) resulted in no significant differences between treatment and control plots (Fig. 10). As at the Bernalillo Watershed, the burned plots consistently had more sediment than the control plots in 1996, but the difference was not significant. In 1997, the burned and control plots had similar sediment yields. Total sediment yield was less in 1997 than in 1996 for all plots $\left(1,180\right.$ and $2,070 \mathrm{~kg} \mathrm{ha}^{-1}$ in 1996 from the control and burn, respectively, versus 598 and $630 \mathrm{~kg} \mathrm{ha}^{-1}$ in 1997).

\section{Soil Erosion Bridges}

Treatment, time of collection, and their interaction were not statistically significant for changes in soil surfaces. The treatment plots showed a slight, net rise in the soil surface immediately after the prescribed burn, but the trend was to decline in the 2 following collections in 1996 (Fig. 11). The control plots showed no significant change during 1996. During 1997 there was a trend (not significant) toward increasing soil surface elevation for both the control and burned plots (Fig. 11).

\section{Discussion}

Weather plays an important part in determining prescriptions for fires and effects from fires. The original study plan targeted a late September or October prescribed fire at both sites. Although summer may be the season of most frequent natural fires that result from lightning ignitions within this region (Wright 1980), prescribed fires occur most often in the cool seasons. Land managers schedule fall or winter prescribed fires because they are easier to contain and fire fighting equipment and personnel are not in high demand elsewhere. In the Southwest, the fall and winter periods can have warm days with light breezes, but not high winds, and can have abundant fine fuels to carry a fire in areas that are removed from livestock grazing. In 1995 a period of drought that started at the beginning of the year continued through the summer, so there was little new herbaceous or grass growth. In September 1995, the rains exceeded the long-term average (Fig. 1b) and forced both burns to be delayed. The prescribed fires were performed later in the fall (Bernalillo Watershed) or winter (West Mesa) when prescribed weather conditions were met. Little or no precipitation occurred after the fires with belownormal precipitation continuing through the winter and spring of 1996. Rains finally came in June of 1996, in the form of thundershowers, and higher-than-average 


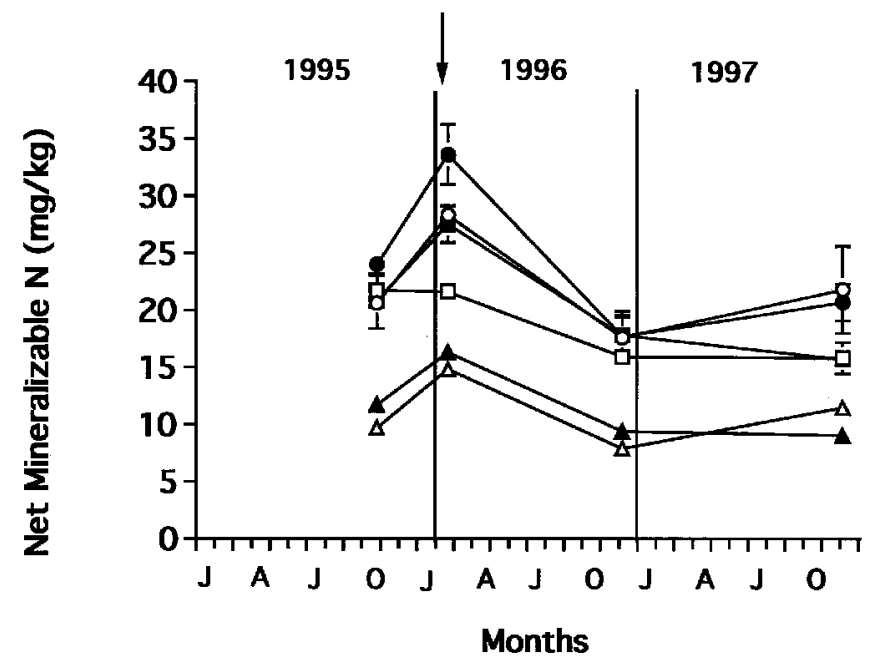

Fig. 9. Changes in mean $( \pm S E)$ mineralizable $N$ content of soils beneath different vegetation cover types (circles, shrub; squares, grass; triangles, bare soil) on the control (open symbols) and burned (filled symbols) plots at the West Mesa. Arrow indicates when the prescribed burn occurred.

precipitation occurred in most months during the rest of the study. The weather also limited the expected benefits from ash on the burned plots because ash was blown off the burned plots, which was evident from ash trapped by vegetation in the surrounding area.

The weather before and after the prescribed fires, and the drought in particular, was the most important factor contributing to changes in plant cover and soil characteristics during this study. The effect of weather, represented by the time-of-collection factor in the statistical analyses, and/or its interaction with the fire treatment were significant factors for all the characteristics at the Bernalillo Watershed and for 2 (vegetation cover and soil mineralizable $N$ ) of the 4 characteristics at the West Mesa. The fire treatment was significant only for 1 characteristic (soil erosion bridge measurements) at Bernalillo Watershed and, along with its interaction with time of collection, for only 1 characteristic (vegetation cover) at West Mesa.

The primary management objective of the prescribed fires was to reduce shrub cover to maintain grasslands. This objective was met at the West Mesa (6.1 and 0.4 average percent shrub cover on control and treatment plots, respectively, after the fire), but not at the Bernalillo Watershed. The lack of fire effects on vegetation cover may have resulted from lower fuel continuity at the Bernalillo Watershed relative to the West Mesa. Shrub cover was not reduced at the Bernalillo Watershed where large patches were unburned, even when the area was treated with fire lines at 10-m intervals. In contrast, better fuel continuity allowed a single fire line to spread across the entire plot at the West Mesa where shrub cover was significantly reduced on the burn plots.

Shrub cover tended to decline at the Bernalillo Watershed over the study at both the control and burned plots. The fire treatment was more effective at reducing the grass cover at the West Mesa than at the Bernalillo Watershed. The fire significantly reduced grass cover at the West Mesa, but the reduction in grass cover was not significant at the Bernalillo Watershed. The lack of fuel continuity at the Bernalillo probably limited consumption of grass fuels, but the drought caused a concurrent reduction in grass cover at the control sites (Fig 4). Grass cover was The first runoff events occurred in early July, 1996. almost the same on the burned and control plots at both sites by the end of 1997 , approximately 2 years after the fire. The increase in grass cover on the burned plots indicates the ability of these grasslands to rapidly respond to fire, while the shrubs show limited recovery after fire or drought in both sites. Research from other semiarid grasslands suggest that stimulation of grass growth occurs for up to 4 years following fires in semiarid grasslands (Bock and Bock 1990, Pase and Granfelt 1977). Thus, grass cover in the burn plots may continue to increase while shrub response may be a factor of weather that is independent of the fires.

Ash from low-intensity fires can contain large amounts of $\mathrm{NH}_{4}-\mathrm{N}$ and other essential nutrients (DeBano 1991, DeBano et al. 1998). The increase in nutrients can stimulate soil microbial activity and increase mineralizable $\mathrm{N}$, but this response was not seen following the fires at these sites (with the possible exception of soils under grass at West Mesa). The lack of fire effects on soil mineralizable $\mathrm{N}$ may be the result of loss of ash due to wind. In the Bernalillo Watershed, redistribution of ash was particularly important because the control plots were "islands" within the treated area and could receive ash from all sides. In contrast, the treatment plots were "islands" within the sea of unburned grasslands at the West Mesa site, so potential ash contribution to the control plots may have been less at the West Mesa site than at the Bernalillo Watershed. The low levels of mineralizable $\mathrm{N}$ in both grasslands suggest that net primary production could be limited by available $\mathrm{N}$ supply; however, fire

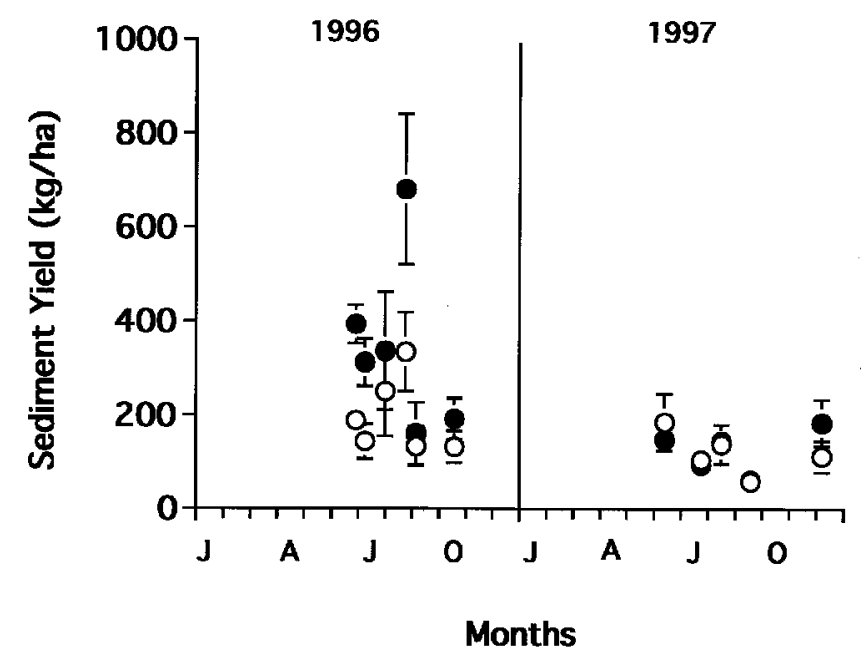

Fig. 10. Amount of mean $( \pm \mathrm{SE})$ sediment yield from the runoff collectors in the control (open circles) and burned (filled circles) plots during 1996 and 1997 at the West Mesa. When paired filled circle is not visible, the values of control and burned plots are nearly equal. 


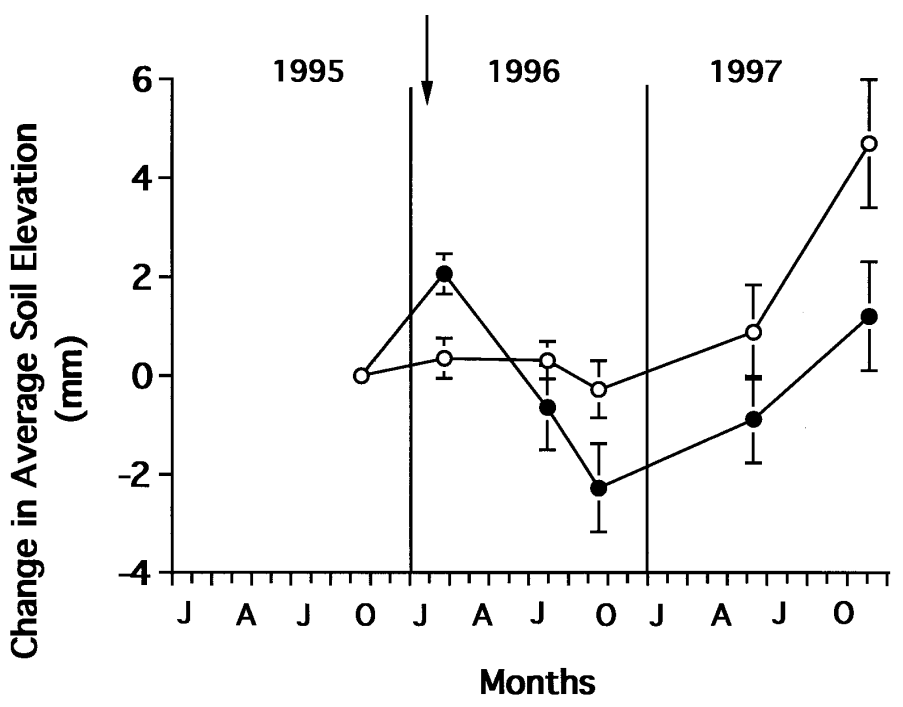

Fig. 11. Mean $( \pm \mathrm{SE})$ net change in the soil surface measured below the erosion bridges within the control (circles) and burned (filled circles) plots at the West Mesa. Arrow indicates when the prescribed burn occurred.

should not change future site productivity since soil mineralizable $\mathrm{N}$ pools were unaffected by fire throughout this study. Soil mineralizable $\mathrm{N}$ pools declined in treatment and control plots at both sites between the second and third collections (except for bare soils at West Mesa). The decline in mineralizable $\mathrm{N}$ coincided with an increase in grass cover, which suggests that part of the available $\mathrm{N}$ pool may have been sequestered by the vegetation. However, the decline in mineralizable $\mathrm{N}$ also may be due to loss of soil and nutrients through sediment transport since sediment yield was high on both control and burned plots at both sites during 1996 (Fig. 6 and 10).

The effects of fire generally trend toward an increase in the rate of surface erosion (DeBano et al. 1998). However, fire was a significant factor only for the changes measured by the soil erosion bridges at the Bernalillo Watershed. The trend toward increasing vegetation cover during 1996 and 1997 is consistent with a decline in sediment $(1,180$ and $2,070 \mathrm{~kg}$ $\mathrm{ha}^{-1}$ in 1996 from the control and burn, respectively, versus 598 and $630 \mathrm{~kg} \mathrm{ha}^{-1}$ in 1997), but weather was a more significant factor than fire controlling sediment yield at the Bernalillo Watershed and the trends at the West Mesa were not significant. The total amount of sediment at both sites was within the range found by Wilcox (1994) using identical sized plots within pinyonjuniper woodlands. The trend at both sites toward lower sediment yield over the course of each summer also was observed by Wilcox (1994), and Yair et al. (1980) observed similar declines in sediment con- centrations with repeated runoff events in arid regions of the northern Negev in Israel. Since similar amounts of and patterns in sediment yield occur elsewhere, control over the changes in sediment yield in this study is likely from causes other than fire. Thus, there is no direct evidence that fire increased the potential for soil erosion at either site although vegetative cover was reduced by the fires.

The soil bridges measured changes in soil surfaces on only a small portion of each runoff/sediment collector. Although the changes over time were significant only at the Bernalillo Watershed, the bridges at both sites showed similar trends with the tendency for the mean soil elevation to decline during 1996 and then increase in 1997. Calculation of the average change in mean soil elevation based upon the sediment yields, assuming that the very topmost soil has a bulk density of $1 \mathrm{~g} \mathrm{~cm}^{-3}$, shows that the total amount of sediment lost during 1996 would represent a decline of $0.09 \mathrm{~mm}$ and $0.14 \mathrm{~mm}$ in the mean soil surface on the control and burned plots, respectively, at the Bernalillo Watershed, and $0.12 \mathrm{~mm}$ and $0.2 \mathrm{~mm}$, respectively, at the West Mesa. The soil bridges show much greater loss (1.0 $\mathrm{mm}$ and more) from most plots, except the control plots on the West Mesa (Fig. 7 and 11). Discrepancies between bridges and sediment yield could reflect the problem that measurements at different scales inherently differ, but bridges also reflect changes in the soil surface due to processes other than runoff. Bridges measure within-collector redistribution of particles by wind, compaction of the soil, freeze-thaw lofting of the soil surface, or other phenomenon that are not expressed at the $30-\mathrm{m}^{2}$ scale of the sediment collectors.

\section{Conclusions}

Hypothesized pattern 1: After an initial decline in vegetation cover, grasses should respond more rapidly than shrubs and achieve greater cover relative to shrubs. This occurred on both grasslands, but can not be attributed to fire alone because of the importance of weather.

Hypothesized pattern 2: Nitrogen in ash should increase the amount of mineralizable $\mathrm{N}$ following the fire, but mineralizable $\mathrm{N}$ should return to that of control or unburned soils following regrowth of vegetation. This pattern did not occur because mineralizable $\mathrm{N}$ in both treatment and control soils rose after the fire, perhaps due to ash contribution to control sites. Weather played a more important role in soil mineralizable $\mathrm{N}$ dynamics than did the fire treatment.

Hypothesized pattern 3: High intensity precipitation could increase erosion following burning until the vegetation cover recovers and potential for erosion would decline. Although there was a trend toward high sediment yields with fire, the fires did not significantly increase sediment yield at these sites. Sediment yield showed greater changes between years than with fire treatment, suggesting that other factors play a greater role in controlling erosion than did the fires.

The results of this study are noteworthy for 2 reasons. First, adverse affects of the fire were not realized. Reduction in vegetation cover after the fire coupled with the extended drought conditions were expected to increase sediment yields from burn plots relative to control plots. If erosion increased, nutrients lost with sediments would lower soil fertility. To our surprise, neither soil erosion nor mineralizable $\mathrm{N}$ (our measure of soil fertility) showed adverse effects of fire. Second, our results show that variation in local weather patterns can play an overriding role in vegetation dynamics and erosion at these grasslands. Thus, the potential for adverse effects on local grasslands from use of prescribed fire for shrub control may be minimal even when the fires are followed by adverse weather conditions. 


\section{Literature Cited}

Baker, M.B. 1990. Hydrologic and Water Quality Effects of Fire, p. 31-42. In: J.S. Krammes (tech. coord.), Effects of Fire Management of Southwestern Natural Resources Symposium. Gen. Tech. Rep. RM-191. Fort Collins, Colo.

Belsky, A.J. 1996. Viewpoint: Western juniper expansion: Is it a threat to arid northwestern ecosystems? J. Range Manage. 49:53-59.

Betancourt, J.L., E.A. Pierson, K.A. Rylander, J.A. Fairchild-Parks, and J.S. Dean. 1993. Influence of history and climate on New Mexico piñon-juniper-woolands, $p$. 42-62. In: E.F.Aldon, and D.W. Shaw (tech. coords.), Managing Piñon Juniper Ecosystems for Sustainability and Social Needs: Proceedings of the Symposium, Gen. Tech. Rep. RM-236. Fort Collins, Colo.

Bock, C.E. and J H. Bock. 1990. Effects of Fire on Wildlife in Southwestern Lowland Habitats, p. 50-64. In: J.S. Krammes (tech. coord.), Effects of Fire Management of Southwestern Natural Resources Symposium. Gen. Tech. Rep. RM-191. Fort Collins, Colo.

Briggs, J.M. and D.J. Gibson. 1992. Effect of fire on tree spatial patterns in a tallgrass prairie landscape. Bull. Torrey Bot. Club. 199(3):300-307.

Brooks, K. N., P. F. Ffolliott, H. M. Gregersen, and J. L. Thames. 1991. Hydrology and the Management of Watersheds. Iowa State Univ. Press, Ames, Ia.

Brown, D.E. (ed.) 1982. Biotic Communities of the American Southwest-United States and Mexico. Desert Plants 4(1-4).

Buffington, L.C. and C.H. Herbel. 1965. Vegetation changes on a semidesert grassland range from 1858 to 1963. Ecol. Monogr 35:139-164.

Collins, S. L. and L. L. Wallace Eds. 1990. Fire in North American Tallgrass Prairies. Univ. Oklahoma Press, Norman, Okla.

Cook, K. 1995. Prescribed Fires Benefit Carson National Forest. New Mexico Wildlife. July/August 1995:10-13.

Davenport, D.W., D.D. Breshears, B.P. Wilcox, and C.D. Allen. 1998. Viewpoint: Sustainablility of pinyon-juniper ecosystems-A unifying perspective of soil erosion thresholds. J. Range Manage. 51(2):231-240.

Day, P. R. 1965. Particle fractionation and particle-size analysis, p. 562-566. In: C. A. Day (ed.), Methods of soil analysis Part I: Physical and mineralogical properties including statistics of measurement and sampling. Amer. Soc. Agron. Madison, Wis.

DeBano, L. F. 1977. Influence of Forest Practices on Water Yield, Channel Stability, Erosion, and Sedimentation in the Southwest. Proc. Soc. Amer. For. Natl. Conv., Oct. 1977, Washington, D. C.

DeBano, L.F. 1991. The effect of fire on soil properties, p151-156. In: A.E. Harvey and Neuenschwander, compilers. Proceedings: Management and Productivity of Wester Montane Forest Soils. USDA Forest Service, Gen. Tech. Rep. INT-280, Fort Collins, Colo.
DeBano, L.F., D.G. Neary, and P.F. Ffolliott. 1998. Fire's Effects on Ecosystems. Wiley \& Sons, New York.

Frederickson, E., K.M. Havstad, R. Estell, and P. Hyder. 1998. Perspectives on desertification: south-western United States. J. Arid Environ. 39:191-207.

Gottfried, G.J., T.W. Swetnam, C. D. Allen, J. L. Betancourt, and A. L. Chung MacCoubrey. 1995. Pinyon-Juniper Woodlands, p. 95-132. In: D.M. Finch and J.A. Tainter (tech. eds.), Ecology, Diversity and Sustainability of the Middle Rio Grande Basin. Gen. Tech. Report RMGTR-268, Fort Collins, Colo.

Hurlbert, S.H. 1984. Pseudoreplication and the design of ecological field experiments. Ecol. Monogr. 54:187-211.

McDaniel, K.C., C.R. Hart, and D.B. Carroll. 1997. Broom snakeweed control with fire on New Mexico blue grama rangeland. J. Range Manage. 50(6):652-659.

Mitchell, J. D. 1978. The American Indian: A fire ecologist. Amer. Indian Culture Res. J. 2(2):26

Molles, M.C., Jr., C.N. Dahm, and M.T. Crocker. 1992. Climate variability and streams and rivers in semi-arid regions, p. 197-202. In: R.D. Robarts and M.L. Bothwell (eds.), Aquatic Ecosystems in Semi-Arid Regions: Implications for Resource Management. N.H.R.I. Symposium Series 7, Environment Canada, Saskatoon.

Morgan, R. P. C. and R. J. Rickson (eds). 1995. Slope Stabilization and Erosion Control: A Bioengineering Approach. Chapman and Hall, New York, N.Y.

New Mexico Water Quality Control Commission (NMWQCC). 1994. Water Quality Water Pollution Control in New Mexico. A Report prepared for submission to the Congress of the United States by the State of New Mexico pursuant to Section 305(b) of the Federal Water Pollution Control Act. Sept. 1994. Santa Fe, N.M.

Parsons, A.J., A.D. Abrahams, and J. Wainwright. 1996. Responses of interrill runoff and erosion rates to vegetation change in southern Arizona. Geomorphology 14:311-317.

Pase, C.P. 1981. Community structure analysis-a rapid, effective range condition estimator for semi-arid lands, p. 425-430. In: H. G. Lund, et al. (tech. coord.), Arid Land Resources Inventories: Developing Cost-efficient Methods. USDA Gen. Tech. Rep. WO28, Washington, D.C.

Pase, C.P. and C.E. Granfelt. 1977. The Use of Fire on Arizona Rangelands. Arizona Interagency Range Committee Publication No. 4. USDA Rocky Mountain Forest Range Sta., Fort Collins, Colo.

SAS. 1989. SAS/STAT ${ }^{\circledR}$ User's Guide, Version 6, Fourth Edition. SAS Institute Inc., Cary, N.C.

Shakesby, R.A. 1993. The soil erosion bridge: a device for micro-profiling soil surfaces. Surface Processes Landforms 18:823-827.

SPSS Inc., 1990. SPSS/PC+ 4.0 Base Manual. SPSS Inc., Chicago, Ill.
Vitousek, P.M., and R.W. Howarth. 1991. Nitrogen limitation on land and in the sea: can it occur? Biogeochemistry 13:87-115.

Watt, A. S. 1947. Pattern and process in the plant community. J. Ecol. 35:1-22.

Weltz, M. and M.K. Wood. 1986. Short-duration grazing in central New Mexico: effect on sediment production. J. Soil Water Conserv. 41:262-266.

White, C.S. 1986. Monoterpenes: their effects on ecosystem nutrient cycling. J. Chem. 20(6):1381-1406.

White, C. S., and M. McDonnell. 1988. Nitrogen cycling processes and soil characteristics in an urban versus rural forest. Biogeochemistry 5:243-262.

Wilcox, B.P. 1994. Runoff and erosion in intercanopy zones of pinyon-juniper woodlands. J. Range Manage. 47:285-295.

Wilcox, B.P, J. Pitlick, and C.D. Allen. 1994. Frijolito Watershed: Integrated Investigations of a Rapidly Eroding Pinyon-Juniper Hillslope. Semiarid Hydrology Conference, Tucson, Ariz., Nov. 1-3, 1994. LA-UR 94-3833.

Wood, J.C., M.K. Wood, and J.M. Tromble. 1987. Important factors influencing water infiltration and sediment production on arid lands in New Mexico. J. Arid Environ. 12:111-118.

Wright, H.A. 1980. The Role and Use of Fire in the Semidesert Grass-Shrub Type. Gen. Rep. INT-85, Ogden, Utah.

Wright, H.A., and A.W. Bailey. 1982. Fire Ecology: United States and Canada. John Wiley \& Sons, Inc., New York, N.Y.

Yair, A., D. Sharon, and H. Lavee. 1980. Trends in runoff and erosion processes over an arid limestone hillside, northern Negev, Israel. Hydrological Sci. J. 25:243-255. 